\title{
Bacterial consumption of DOC during transport through a temperate estuary
}

\author{
Peter A. Raymond*, James E. Bauer \\ School of Marine Science, College of William and Mary, Gloucester Point, Virginia 23062, USA
}

\begin{abstract}
Bacterial utilization of natural levels of dissolved organic carbon (DOC) was measured in the York River estuary, a sub-estuary of the Chesapeake Bay. This study was undertaken in order to elucidate spatial and temporal changes in bacterial carbon utilization and to evaluate its importance as a pathway for organic matter transformation in estuaries. Multiple pools of DOC were defined based on decomposition kinetics. The first pool $\left(\mathrm{G}_{1}\right)$ made up a mean of $2.8 \%$ of total DOC and had turnover times of $\leq 5 \mathrm{~d}$. The second pool $\left(\mathrm{G}_{2}\right)$ comprised an average of $4.9 \%$ of total DOC and had turnover times of $\sim 1$ mo. Our data indicate that although the total amount of DOC utilized was low, there was a continual supply of both the $\mathrm{G}_{1}$ and $\mathrm{G}_{2}$ fractions within the estuary. Bacterial growth efficiency on the $\mathrm{G}_{1}$ pool averaged $28 \%$. The production of $\mathrm{CO}_{2}$ through bacterial respiration of the $\mathrm{G}_{1}$ pool could not balance $\mathrm{CO}_{2}$ evasion for the majority of the estuary. Bacterial DOC degradation in the York River estuary was limited by temperature for the majority of the year. This temperature constraint coupled with relatively short hydrologic residence times resulted in the export of labile DOC from the estuary prior to complete bacterial decomposition. We estimate that $\sim 10 \%$ of the riverine DOC exported annually from estuaries to the mid-Atlantic Bight (MAB) is a labile fraction of DOC that is not utilized within the estuaries due to temperature constraints on estuarine bacteria. This DOC is not inherently recalcitrant and is an allochthonous source of labile DOC for the coastal MidAtlantic Ocean.
\end{abstract}

KEY WORDS: Dissolved organic carbon (DOC) $\cdot$ Heterotrophy $\cdot$ Mid-Atlantic Bight · Carbon export · Chesapeake Bay · York River

Resale or republication not permitted without written consent of the publisher

\section{INTRODUCTION}

In oceans, lakes, rivers, and estuaries alike, dissolved organic carbon (DOC) represents an important potential source of reduced carbon for heterotrophic bacterial metabolism. Nevertheless, our understanding of many aspects of DOC turnover by bacteria is lacking. For example, it is currently unclear where and how the majority of terrestrial DOC, transported to oceans via rivers and estuaries, is removed from the carbon cycle (Hedges et al. 1997). Rivers and estuaries export $0.2 \times 10^{15} \mathrm{~g}$ of DOC annually (Meybeck 1982), which represents a flux more than twice that of the estimated oceanic DOC turnover of $0.1 \times 10^{15}{\mathrm{~g} \mathrm{C} \mathrm{yr}^{-1}}^{-1}$

\footnotetext{
${ }^{*}$ Present address: Marine Biological Laboratory, Ecosystems Center, Woods Hole, Massachusetts 02543, USA.

E-mail: praymond@mbl.edu
}

(Williams \& Druffel 1987, Bauer et al. 1992). Rivers and estuaries are generally considered to be net heterotrophic, which requires that they receive supplements of allochthonous organic matter to fuel a percentage of their metabolism (see reviews by Smith \& Hollibaugh 1993, Heip et al. 1995, Gattuso et al. 1998). Because riverine and estuarine bacteria can readily oxidize certain components of the DOC pool (Kirchman et al. 1991, Findlay et al. 1992, Coffin et al. 1993, Amon \& Benner 1994), it seems likely that microbial utilization of DOC contributes substantially to net heterotrophy in rivers and estuaries. However, this has not been shown previously by direct measurements.

DOC is composed of discrete pools of biomolecules with turnover times ranging from hours (Coffin et al. 1989, Fuhrman 1990), to days (Coffin et al. 1993, Søndergaard et al. 1995), to months (Fry et al. 1996, Carlson et al. 1999) to millennia (Williams \& Druffel 1987). 
This continuum of reactivity is described in the multi-G model (Berner 1980, Westrich \& Berner 1984), where the decay (i.e., removal) of organic matter is dictated by the sequential loss of discrete pools with decreasing decay constants. Previous studies have not generally observed a relationship between DOC concentrations and indicators of bacterial activity and growth (i.e., bacterial production and abundance) in rivers and estuaries (Findlay et al. 1996, Basu \& Pick 1997). This may be due, in part, to the continuum of reactivity within the DOC pool, because it is sometimes a small percentage of the DOC pool that supports the majority of bacterial carbon utilization (Wright \& Hobbie 1965, Kirchman et al. 1991, but see Amon \& Benner 1996). Søndergaard \& Middelboe (1995) found that the average percentage of labile (defined as the amount utilized in $\leq 7 \mathrm{~d}$ ) DOC in lakes, rivers, and marine systems was 14,19 , and $19 \%$ of the total DOC pool, respectively. Across systems the concentration of labile DOC generally increased with increasing total DOC concentrations, with an average response of an additional $0.17 \mu \mathrm{M}$ labile DOC for every $1.0 \mu \mathrm{M}$ increase in total DOC (Søndergaard \& Middelboe 1995).

Labile DOC may be differentiated from total DOC in a semi-quantitative manner through bioassays. Bioassays are performed by filtering water, to remove particulate organic carbon (POC) and grazers, and measuring the change in oxygen, inorganic carbon, DOC, or bacterial parameters over a specified time interval. During experimental incubations, bacteria are removed from their natural setting, and interactions between bacteria and viruses, grazers, temperature, or nutrients can be altered. Longer incubations (i.e., days to months) may also overlook in situ processes that create labile DOC on very short timescales. Examples of such processes include photo-oxidation (Amon \& Benner 1996, Bano et al. 1998, Moran et al. 1999), algal exudation (Cole et al. 1982, Baines \& Pace 1991), and sloppy feeding (Roy et al. 1996). It is important to note that because they often eliminate the effects of these processes, incubations assess only the standing stock of labile DOC at a given time. Thus, extrapolating degradation rates and fluxes from incubations to the field may result in a misrepresentation.

In this study, we report on the pool sizes and turnover rates of DOC utilized by heterotrophic estuarine bacteria on both short timescales $(\sim 5 \mathrm{~d})$, and on timescales relevant to estuarine residence times ( 1 mo). Experiments were also performed to elucidate the relative impor- tance of temperature, inorganic nutrients, and DOC concentration on DOC utilization. The results of this study are used to estimate the importance of bacterial carbon utilization with respect to net heterotrophy observed in the York River estuary (inferred from $\mathrm{pCO}_{2}$ super-saturation by Raymond et al. in press). We also estimate the amounts of labile and refractory terrestrial DOC transported through the York River estuary to the Chesapeake Bay and mid-Atlantic Bight (MAB).

\section{MATERIALS AND METHODS}

Study site: York River estuary. The York River estuary is a sub-estuary of the Chesapeake Bay formed by the convergence of the Pamunkey and Mattaponi Rivers approximately $50 \mathrm{~km}$ from its mouth (Fig. 1). The Pamunkey contributes approximately $70 \%$ of the total flow to the York River estuary (data from the US Geological Survey at http://water.usgs.gov/) and is flanked by tidal freshwater marshes and swamps, with some individual marshes being greater than $4 \mathrm{~km}^{2}$ in size (Silberhorn \& Zacherle 1987). The York River estuary is considered pristine amongst the sub-estuaries of the Chesapeake Bay (Bender 1986), the only industry being a paper pulp plant at the convergence of the Pamunkey \& Mattaponi Rivers.

Bacterial production in the York River estuary increases with decreasing salinity (Koepfler 1989, Schultz 1999) and is strongly related to temperature, with production rates being 3 -fold greater in summer than in winter months (Koepfler 1989). Phytoplankton

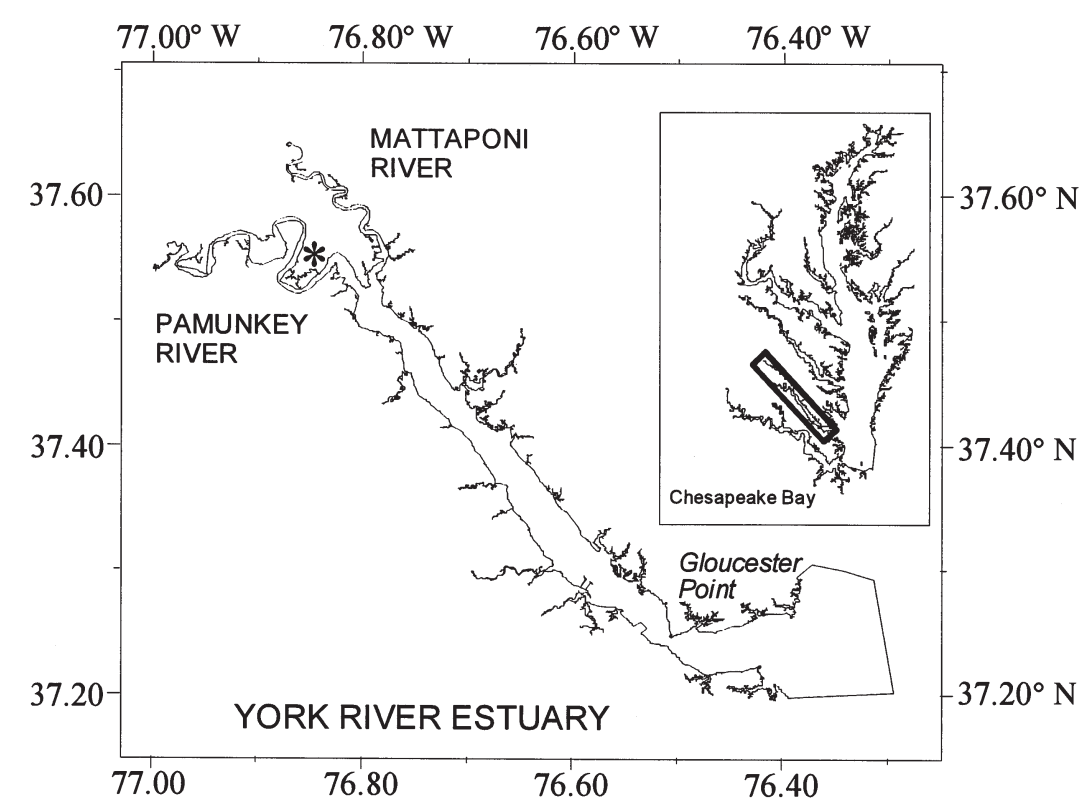

Fig. 1. The York River estuary system, showing its location relative to Chesapeake Bay 
exhibit late-winter/early-spring blooms in the mesohaline reaches of the York system, and weaker summer blooms in the upper low salinity reaches (Sin et al. 1999). Net heterotrophy in the York River estuary (where respiration > gross primary production) has been established as the dominant contributor to the observed $\mathrm{pCO}_{2}$ super-saturation (Raymond et al. in press).

Monthly sampling transects were performed along the mid-channel axis that stretched from the mouth of the York River esuary to the freshwater end-member. The average salinity range for all transects was 0 to $18 \%$. Incubations were set up at 5 stations. The locations of the stations were not fixed in order to ensure that the salinity range was adequately covered.

Experimental incubations. In order to minimize the time between sample filtration and the start of an incubation, incubations was set up in the field. Approximately $5 \mathrm{l}$ of water were filtered sequentially through baked $\left(\sim 550^{\circ} \mathrm{C}\right) 142 \mathrm{~mm}$ diameter GF/D (effective pore size of $2.7 \mu \mathrm{m}$ ) and GF/F glass fiber filters (effective pore size of $0.7 \mu \mathrm{m}$ ) to remove particulate organic matter and bacterial predators. Filters were changed frequently to minimize cell lysis and occlusion of filters by the high POM load. An average of $13 \pm 22 \%$ of the total bacteria population was removed during filtration in the present study (data not shown). At each site, two 11 polycarbonate bottles (cleaned with $10 \% \mathrm{HCl}$ and Nanopure water) were filled with $500 \mathrm{ml}$ of filtered water, and a time-zero sample was taken according to the methods outlined below. The incubation bottles were then placed in a cooler of river water in the dark to maintain in situ temperatures, and brought to the lab.

Once in the lab the incubation bottles were placed in a temperature-controlled chamber, and incubated in the dark at in situ temperatures. A total of 40 incubations were carried out between September 1996 and September 1997. Generally, the incubations were subsampled at 1, 5, 14, and $28 \mathrm{~d}$. The actual time of sampling, particularly the 1 mo time point, was not identical between transects, and the removal of DOC was normalized to 5 and $28 \mathrm{~d}$ in order to facilitate accurate comparison. The average coefficient of variation for DOC measurements for a time point between bottle replicates was $0.8 \%$.

Factorial experiments. Experiments were conducted in December 1996, March 1997, and May 1997 to evaluate the effects of various parameters on DOC utilization. These experiments followed a $2 \times 2 \times 2$ orthogonal design (Fig. 2), and included both in situ and elevated levels of temperature, DOC, and nutrients. Treatments included: (1) $50 \mu \mathrm{M}$ additions of high molecular weight (i.e., 'Colloidal') in situ DOC (2) 2.5 and $1.0 \mu \mathrm{M}$ additions of ammonium and phosphate, respectively; and (3) an elevated $\left(25^{\circ} \mathrm{C}\right)$ temperature treatment. The various treatment combinations gave a total of 8 discrete treatments (Fig. 2), and each treatment was performed in duplicate. Water for the factorial experiments was collected from the transitional zone of the estuary (salinity $\approx 7$ to 8.5 ) and filtered in the laboratory. There was a time lag of about $4 \mathrm{~h}$ between the time of sample collection and when the factorial incubation was started. This was the time required to ultra filter high molecular weight DOC for the DOC treatments. Samples were collected periodically from the incubation bottles following the protocol outlined below.

Dissolved organic carbon. For DOC analysis, $4 \mathrm{ml}$ of filtered incubation water was pipetted into duplicate, baked $7 \mathrm{ml}$ vials, acidified with $25 \mu \mathrm{l}$ of high purity $10 \% \mathrm{HCl}$ and frozen until the complete time-series could be analyzed concurrently. Caps for the vials were acid soaked, rinsed, and lined with baked aluminum foil. Concentrations of DOC were measured on a Shimadzu TOC-5000A high temperature analyzer, using a 4-point calibration curve with glucose as a standard. De-ionized water blanks were run after every 10 samples. The average coefficient of variation for duplicate DOC analyses was $1.2 \%$.

High molecular weight organic matter collection. All sample water was filtered through $10 \% \mathrm{HCl}-$ cleaned $0.2 \mu \mathrm{m}$ polypropylene filter capsules (MSI Corp., MA, USA). High molecular weight ( $\geq 1 \mathrm{kD}$ ) dissolved organic matter was then concentrated by ultrafiltering 141 of York River estuary water using an Amicon DC-10 concentrator equipped with 2 S10N1 spiral-wound polysulfone cartridges (Benner et al. 1992, Bauer et al. 1996, Buesseler et al. 1996). Samples were concentrated to approximately 11 final volume and then added to incubation bottles in order to obtain final concentrations that were $\sim 50 \mu \mathrm{M}$ higher than in

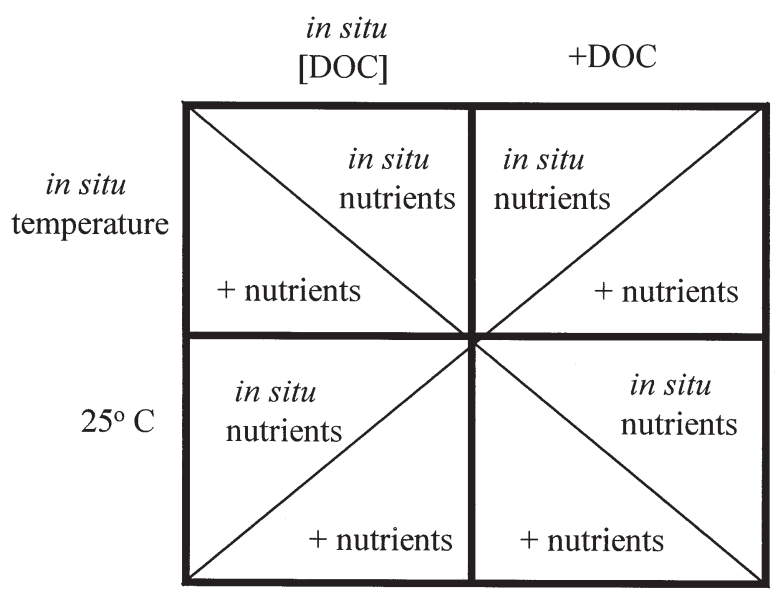

Fig. 2. Design of factorial experiments. Factorials were a $2 \times 2$ $\times 2$ orthogonal design. For the +nutrient treatments, we added $1 \mu \mathrm{M}$ of $\mathrm{PO}_{4}{ }^{3-}$, and $2.5 \mu \mathrm{M}$ of $\mathrm{NH}_{4}{ }^{+}$, while for the +DOC treatments we added approximately $50 \mu \mathrm{M}$ of in situ concentrated colloidal organic carbon. Experiments were run in the dark using filtered water at in situ temperatures and at $25^{\circ} \mathrm{C}$ 
situ DOC concentrations. Recoveries of high molecular weight DOC were 65, 57, and 59\% for the December 1996, March 1997, and May 1997 factorial experiments, respectively. Concentration factors were 20, 18 , and 25, respectively, for these 3 sampling events.

Bacterial numbers, biomass, and growth efficiency. Bacterial abundance was measured on the 0 and $5 \mathrm{~d}$ samples to estimate bacterial growth efficiency (BGE). Samples for bacterial enumeration were collected in all experiments, but we chose to estimate the change in bacterial biomass and BGE only for incubations that had slopes significantly different from zero when calculating DOC decay constants. We included the January 1997 samples even though they were not continued past $5 \mathrm{~d}$. This amounted to 18 independent estimates of net bacterial growth and BGE.

For bacteria enumeration, $2 \mathrm{ml}$ of incubation water were stained with acridine orange and filtered onto stained Poretics $0.2 \mu \mathrm{m}$ polycarbonate membrane filters (Hobbie et al. 1977). For each replicate incubation bottle, duplicate slides were prepared for each time point. This amounted to a total of 4 slides for each time point. At least 200 bacteria were counted per slide on an Olympus BX40 epifluorescence microscope. The average coefficient of variation for bacterial numbers between replicate bottles for a given time point was $5.6 \%$.

To convert the initial bacterial numbers to biomass we used an average biovolume estimate of $0.6 \mu^{3}$ per cell for bacteria from the York River estuary (Ducklow 1982,

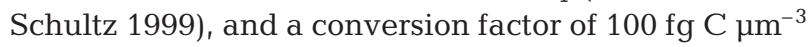
(Carlson et al. 1999). Bacterial cell volumes often increased during the course of an incubation, so for the $5 \mathrm{~d}$ time points we used this same carbon conversion factor but assumed a $15 \%$ increase in bacterial volume (Ducklow et al. 1989). The change in bacterial biomass is reported as the change in bacterial carbon between the initial and $5 \mathrm{~d}$ time points, and BGE as the increase in bacterial biomass divided by the change in DOC. The mean deviation for the increase in bacterial biomass between replicate incubations averaged $0.4 \mu \mathrm{M}(15 \%)$.

\section{RESULTS}

\section{DOC utilization}

A representative time course of DOC utilization at different salinities in the York River estuary is shown in Fig. 3. In most cases (except January 1997) the incubations were conducted for $28 \mathrm{~d}$. A rate constant was calculated for incubations that were carried out past the $5 \mathrm{~d}$ time points according to the following equation:

$$
\frac{\Delta \ln C}{\Delta t}=-k \times C
$$

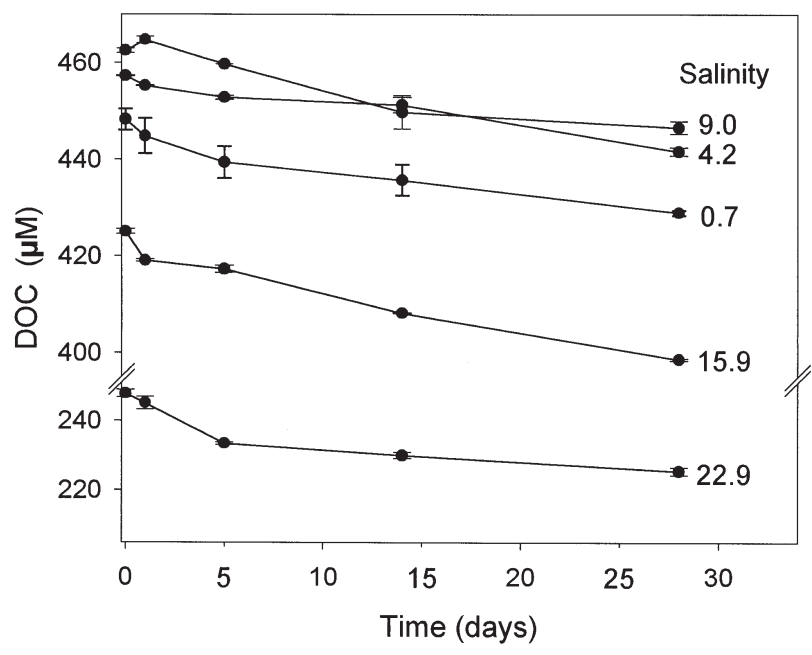

Fig. 3. Representative DOC utilization time series for a York River estuary transect. Incubations were conducted with $0.7 \mu \mathrm{m}$ filtered water, set up in the field, and incubated in the dark at in situ temperatures. Error bars are mean \pm standard errors for duplicate incubations

where $C$ is the DOC concentration $(\mu \mathrm{M}), t$ is time (in days), and $k$ is the first order rate constant (in $\mathrm{d}^{-1}$ ). The $k$ value is also the slope of the line when $\ln C$ is plotted as a function of time. For our data, the average $k$ value obtained when all data points were included (i.e., 0 to $28 \mathrm{~d})$ was $-2.4 \pm 1.8 \times 10^{-3} \mathrm{~d}^{-1}$.

A more labile pool that is utilized within the first few days of incubation is often found in rivers and estuaries. We originally implemented our $1 \mathrm{~d}$ time point in order to assess this pool. Unfortunately, a decrease in DOC was not always measured after a single day of incubation. This may be due to a lag time associated with the removal of a significant percentage of bacteria during filtration (Ferguson et al. 1984). Therefore the $1 \mathrm{~d}$ time points could not be used for the purpose of evaluating the most labile DOC pool and we were forced to use the $5 \mathrm{~d}$ time point. In an attempt to constrain the more labile DOC pool, and in accordance with the multi-G model, we differentiated the DOC utilized during $28 \mathrm{~d}$ into 2 fractions. The first, more labile pool $\left(G_{1}\right)$ was removed during the first $5 \mathrm{~d}$, and the second, less labile pool $\left(\mathrm{G}_{2}\right)$ was removed between 5 and $28 \mathrm{~d}$. The average $k$ for the $\mathrm{G}_{1}$ pool was $-4.8 \pm 4.5 \times 10^{-3} \mathrm{~d}^{-1}$, while the average $k$ for the $\mathrm{G}_{2}$ pool was $-2.2 \pm 1.4 \times 10^{-3} \mathrm{~d}^{-1}$.

The percentages of labile DOC removed after 5 and $28 \mathrm{~d}$ for all 40 incubations are plotted as a function of salinity in Fig. 4. During the first 5 d, the average percent DOC removed at in situ temperatures for all transect incubations was $2.8 \pm 2.3 \%$, with a range of 0.2 to $12 \%$ (Fig. 4a). After $28 \mathrm{~d}$ the percent DOC removed at in situ temperatures for all transect incubations rose to $7.7 \pm 5.0 \%$, with a range of 1 to $23 \%$ (Fig. 4 b). Therefore, $2.8 \%$ of the total DOC pool was utilized after $5 \mathrm{~d}$, 

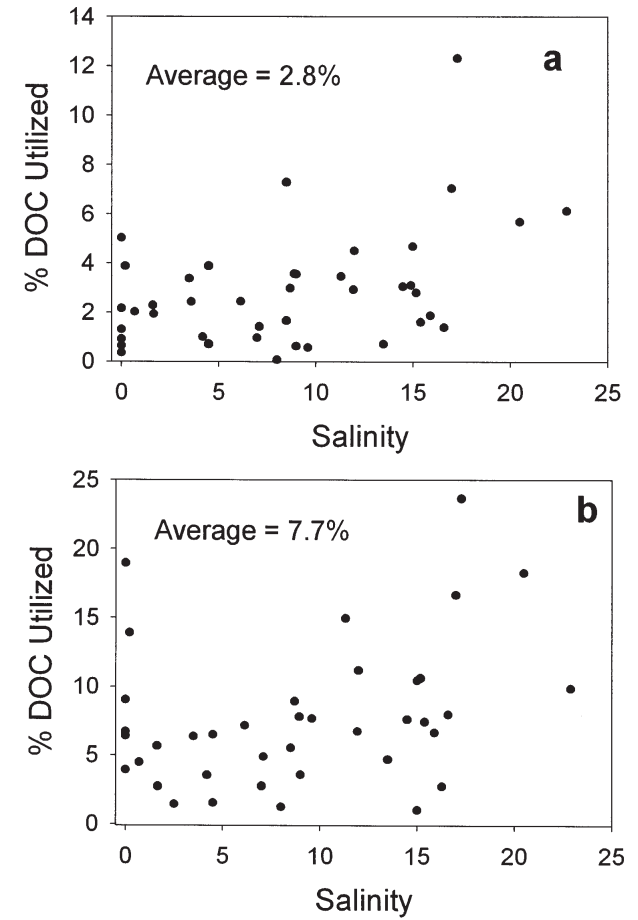

Fig. 4. Percentage of DOC utilized by bacteria during all transect incubations after (a) $5 \mathrm{~d}$, and (b) $28 \mathrm{~d}$

and an additional $4.9 \%$ (7.7 to $2.8 \%$ ) was utilized during the subsequent $23 \mathrm{~d}$ of incubation. Neither seasonality nor significant effects of salinity or temperature were found to affect DOC utilization when the $5 \mathrm{~d}$ time points were analyzed.

The $28 \mathrm{~d}$ time points (Fig. 4b) indicated that relatively high percentages of labile DOC were present in the freshwater samples (average: $9.1 \pm 5.1 \%$ ), lower percentages $(\leq 6 \%)$ at low salinities (1 to $5 \mathrm{psu}$ ), and a steady increase in the percent lability from salinities 5 to 20. A weak seasonal pattern to DOC consumption when examining the $28 \mathrm{~d}$ time points was also seen. Generally, there was greater use in the summer through mid-fall and less in late fall and spring (data not shown). We attribute low DOC utilization in late fall/spring to changing water temperatures, but we lack a complete low temperature time series to support this because the January incubation was ended abruptly after $5 \mathrm{~d}$ when the incubation chamber failed. The inclusion of a January time series may have strengthened our argument that low seasonal temperatures depressed DOC utilization. The factorial incubations further elucidate the effects of temperature, nutrients, and DOC level on DOC utilization (see below).

\section{Bacterial growth}

The average increase in bacterial biomass after $5 \mathrm{~d}$ of incubation was $2.5 \pm 0.5 \mu \mathrm{M} \mathrm{C}\left(0.5 \mu \mathrm{M} \mathrm{C} \mathrm{d}^{-1}\right)$ and ranged from 1.1 to $6.9 \mu \mathrm{M} \mathrm{C}$ (Table 1). Over this same

Table 1. Net bacterial production, bacterial DOC utilization, \% DOC used, and bacterial growth efficiency from $5 \mathrm{~d}$ incubations with York River estuary water. Bacterial efficiencies (Bacterial production/DOC utilized) were calculated only for incubations that had a significant slope ( $\mathrm{p}<0.05$ at $95 \%$ confidence interval) when calculating decay constants using all time points. Incubations were conducted at in situ temperatures of $22,10,5,10,20$, and $27^{\circ} \mathrm{C}$ for the September, November, January, March, May, and July incubations, respectively. SE: mean standard error of duplicate incubations; nd: not determined

\begin{tabular}{|c|c|c|c|c|c|c|c|}
\hline \multirow{2}{*}{$\begin{array}{l}\text { Date } \\
(\mathrm{mo} / \mathrm{d} / \mathrm{yr})\end{array}$} & \multirow[t]{2}{*}{ Salinity } & \multicolumn{2}{|c|}{ Bacterial production $(\mu \mathrm{M})$} & \multicolumn{2}{|c|}{ DOC utilized $(\mu \mathrm{M})$} & \multirow{2}{*}{$\begin{array}{c}\% \text { DOC } \\
\text { consumed }\end{array}$} & \multirow{2}{*}{$\begin{array}{c}\text { Bacterial growth } \\
\text { efficiency (\%) }\end{array}$} \\
\hline & & Mean & $\mathrm{SE}$ & Mean & $\mathrm{SE}$ & & \\
\hline 09/09/96 & 11.3 & 2.0 & nd & 13.4 & 0.16 & 3.5 & 28 \\
\hline \multirow[t]{3}{*}{$11 / 19 / 96$} & 0 & 1.1 & 0.29 & 5.7 & 5.61 & 1.3 & 10 \\
\hline & 9.0 & 2.1 & 0.15 & 15.1 & 2.71 & 3.6 & 14 \\
\hline & 16.6 & 1.4 & 0.06 & 15.7 & 0.93 & 4.7 & 13 \\
\hline \multirow[t]{3}{*}{ 01/17/97 } & 3.6 & 1.8 & nd & 11.3 & 5.14 & 3.6 & 16 \\
\hline & 8.9 & 2.1 & 0.35 & 7.9 & 1.78 & 3.1 & 27 \\
\hline & 14.9 & 3.7 & 0.49 & 9.5 & 0.07 & 2.4 & 38 \\
\hline \multirow[t]{2}{*}{ 03/24/97 } & 0 & 2.6 & 0.08 & 5.3 & 3.99 & 1.9 & 49 \\
\hline & 12.0 & 1.5 & 0.001 & 12.2 & 7.91 & 4.5 & 12 \\
\hline \multirow[t]{4}{*}{ 05/21/97 } & 0 & 4.1 & 1.00 & 9.2 & 2.03 & 2.2 & 44 \\
\hline & 4.5 & 2.4 & 0.10 & 3.2 & 1.01 & 0.7 & 73 \\
\hline & 14.5 & 1.2 & 0.26 & 7.4 & 1.00 & 3.1 & 16 \\
\hline & 17.0 & 2.0 & 0.05 & 15.8 & 0.11 & 7.0 & 12 \\
\hline \multirow[t]{5}{*}{ 07/18/97 } & 0 & 6.9 & 2.11 & 16.5 & 0.36 & 3.9 & 42 \\
\hline & 3.5 & 2.1 & 0.40 & 13.8 & 0.62 & 3.4 & 15 \\
\hline & 8.7 & 3.3 & 1.02 & 13.9 & 8.96 & 3.0 & 24 \\
\hline & 15.4 & 3.0 & 0.37 & 5.31 & 3.63 & 5.7 & 8 \\
\hline & 20.5 & 1.2 & 0.25 & 14.1 & 6.57 & 1.6 & 56 \\
\hline Average & & 2.5 & 0.44 & 10.5 & 3.20 & 3.3 & 27.8 \\
\hline
\end{tabular}


period, BGE (bacterial production/DOC utilization) averaged $28 \pm 18 \%$ and ranged from 8 to $73 \%$ (Table 1). Rates of microbial growth normalized to initial DOC concentrations averaged $1.4 \pm 0.6 \mu \mathrm{M} \mathrm{mM}^{-1}$ $\mathrm{d}^{-1}$, and had a range of 0.5 to $3.1 \mu \mathrm{M} \mathrm{mM}^{-1} \mathrm{~d}^{-1}$. These DOC-normalized rates of growth are generally low, but are similar to the rates reported by Hopkinson et al. (1998) for riverine bacteria.

\section{Factorial experiments}

Responses of bacteria to elevated temperature, DOC, and nutrient treatments were generally evident after $5 \mathrm{~d}$ of incubation (data not shown). The amounts of DOC used after $28 \mathrm{~d}$ of incubation are shown in Fig. 5, while Table 2 reports significance levels for relationships between treatments from general linear ANOVAs. In all of the factorial experiments there was a significant $(p<0.001)$ bacterial response when temperatures were elevated above in situ temperatures

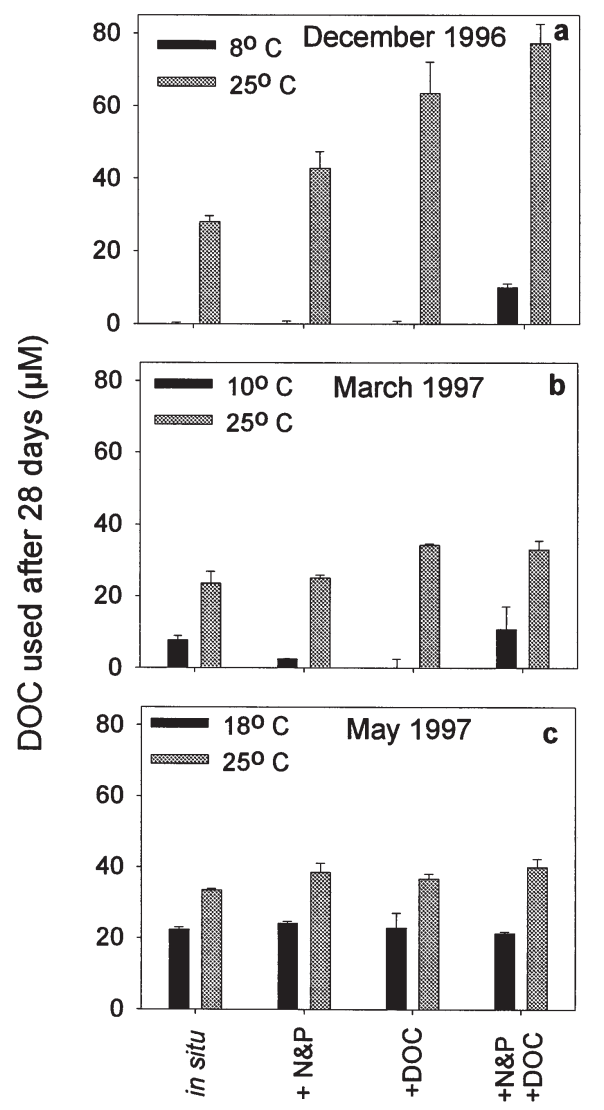

Fig. 5. Results from the 3 factorial experiments, conducted in (a) December 1996, (b) March 1997, and (c) May 1997. The factorial design is shown in Fig. 1. Significant relationships from general linear ANOVAs are reported in Table 2. Error bars represent mean \pm standard error for duplicate incubations
(Fig. 5, Table 2). This indicates that bacterial carbon utilization was constrained by low in situ temperatures. The temperature constraint was evident in both the 5 and $28 \mathrm{~d}$ time points for the December and May experiments (Table 2).

In each factorial experiment the temperature was raised from in situ to $25^{\circ} \mathrm{C}$. In the $25^{\circ} \mathrm{C}$ treatment, the average percentages of DOC used were 12.8, 7.3, and $6.1 \%$ greater than at in situ temperatures for the December, March, and May experiments, respectively. The difference between low and high temperature treatments was 17,10 , and $7^{\circ} \mathrm{C}$ for these same 3 experiments. This equates to a near-constant average (with standard deviation) temperature effect of $0.8 \pm 0.06 \%$ DOC loss per ${ }^{\circ} \mathrm{C}$ change for the 3 experiments.

A weak yet significant response $(p<0.03)$ to nutrient additions was noted in the December factorial experiment only (Fig. 5, Table 2). The inconsistent response to nutrient additions in the 5 and $28 \mathrm{~d}$ time points indicates that nutrient limitation is not a strong factor limiting bacterial carbon utilization in the transect incubations. In 2 factorial experiments there was a significant response to the DOC additions at the $28 \mathrm{~d}$ time point (Table 2). Responses to DOC additions could indicate that at in situ temperatures bacteria are not using DOC at their maximum rate and can therefore be stimulated by the addition of more labile DOC. Statistical evaluation of this effect is hampered by interactions between DOC and temperature (Table 2); i.e., the response to added DOC might only occur at elevated temperatures. Indeed, when 1-way ANOVAs were applied for in situ temperature treatments alone, there was no significant increase in bacterial carbon utilization in the DOC added treatments. The lack of a response to added DOC at lower in situ temperatures indicates that, at temperatures $<18^{\circ} \mathrm{C}$, bacterial carbon utilization was at its maximum rate and was not stimulated further by DOC additions. Shiah \& Ducklow (1994), and Zwiefel (1999) have noted similar interactions between temperature, DOC additions, and bacterial growth.

Our factorial experiments and the aforementioned studies suggest that, at moderate to low in situ temperatures, maximal rates of DOC consumption $\left(C_{\max }\right)$ are limited by temperature. Under these conditions, bacteria are not stimulated further by additional nutrients or labile DOC. Temperate US east-coast estuaries experience temperatures $\leq 18^{\circ} \mathrm{C}$ for a large part of the year and receive both autochthonous and allochthonous inputs of labile DOC (Howarth et al. 1991, Hoch \& Kirchman 1993, Peterson et al. 1994, Fisher et al. 1998, this study). Because of temperature constraints on $C_{\text {max }}$ this labile DOC may accumulate in estuarine waters until $C_{\max }$ rises, or until the labile DOC is exported. 
Table 2. Results of factorial experiments indicating significance of treatment effects on DOC used after $28 \mathrm{~d}$ of incubation. Reported are the starting concentrations, the percentage of colloidal organic matter in ambient water, and results of general linear ANOVA tests. Relationships with an asterix $\left({ }^{*}\right)$ denote when there were also significant differences after $5 \mathrm{~d}$ using general linear ANOVA

\begin{tabular}{|c|c|c|c|}
\hline Date and temperatures & Starting concentrations $(\mu \mathrm{M})$ & Colloidal DOC (\%) & $\begin{array}{l}\text { Significant treatments } \\
\text { ( } F \text { and } p \text { values given) }\end{array}$ \\
\hline $\begin{array}{l}\text { December } 1996 \\
8^{\circ} \mathrm{C} \text { in situ } \\
25^{\circ} \mathrm{C} \text { treatment }\end{array}$ & $\begin{array}{l}\mathrm{DOC}=365 \\
\mathrm{PO}_{4}{ }^{-}=0.4 \\
\mathrm{NO}_{3}^{-}=6.7 \\
\mathrm{NH}_{4}^{+}=5.8\end{array}$ & 65 & $\begin{array}{c}\text { Temperature }(198,<0.001)^{*} \\
\text { DOC }(30,0.001) \\
\text { Temp } \times \text { DOC }(13,0.006)^{*} \\
\text { Nutrients }(7,0.027)\end{array}$ \\
\hline $\begin{array}{l}\text { March } 1997 \\
10^{\circ} \mathrm{C} \text { in situ } \\
25^{\circ} \mathrm{C} \text { treatment }\end{array}$ & $\begin{array}{c}\mathrm{DOC}=284 \\
\mathrm{PO}_{4}{ }^{--}=0.8 \\
\mathrm{NO}_{3}{ }^{-}=12.8 \\
\mathrm{NH}_{4}{ }^{+}=6.5\end{array}$ & 57 & $\begin{array}{c}\text { Temperature }(113,<0.001)^{*} \\
\text { DOC }(10,0.012) \\
\text { Temp } \times \text { DOC }(10,0.012) \\
\text { Temp } \times \text { DOC } \times \text { Nutrients }(7,0.030)\end{array}$ \\
\hline $\begin{array}{l}\text { May } 1997 \\
18^{\circ} \mathrm{C} \text { in situ } \\
25^{\circ} \mathrm{C} \text { treatment }\end{array}$ & $\begin{array}{l}\mathrm{DOC}=298 \\
\mathrm{PO}_{4}{ }^{--}=0.3 \\
\mathrm{NO}_{3}{ }^{-}=3.2 \\
\mathrm{NH}_{4}{ }^{+}=3.4\end{array}$ & 59 & Temperature $(103,<0.001)$ \\
\hline
\end{tabular}

\section{DISCUSSION}

\section{Estuarine DOC utilization}

After $5 \mathrm{~d}$ of incubation, an average of $2.8 \pm 2.3 \%$ of the total DOC pool was used by bacteria in the York River estuary. This average represents the labile pool of DOC as defined by Søndergaard \& Middelboe (1995), and is low compared to the average of $19 \%$ reported by these authors for riverine $(n=16)$ and marine $(n=36)$ systems. A potential source of this discrepancy may be methodological. The studies included in Søndergaard \& Middelboe's (1995) review relied mostly on oxygen consumption and thymidine incorporation to estimate DOC lability (M. Søndergaard pers. comm.). Both of these methods are indirect and have inherent problems. For example, changes in oxygen can be influenced by nitrification, chemical oxygen demand, and varying substrate oxidation states (Søndergaard \& Middelboe 1995, del Giorgio \& Cole 1998). Thymidine incorporation and bacterial biomass estimates rely on various conversion factors that have large uncertainties (Jahnke \& Craven 1995).

It is notable that Søndergaard \& Middelboe (1995) reported that $>50 \%$ of the estuarine/river data had a labile DOC fraction in excess of $25 \%$, which significantly raised their reported average (19\%) for rivers and estuaries. They attributed the $>25 \%$ lability to the proximity of these rivers and estuaries to urbanized areas that may contribute significant quantities of labile DOC. The York River watershed is sparsely populated with only $\sim 2 \%$ of the watershed classified as urban/suburban (Bender 1986), and it contains no major wastewater treatment plants. The low percentage of labile DOC in the York River estuary may be a result of it being a relatively pristine, or historical, endmember with small contributions of labile DOC from urbanization.

Due to the inherent ambiguities associated with measuring oxygen utilization or thymidine incorporation, as stated by Søndergaard \& Middelboe (1995), 'the most direct and unequivocal method is to measure the decrease in DOC'. Del Giorgio \& Cole (1998) add: ‘because most contemporary research in microbial ecology has focused on the regulation of bacterial growth and production, we know relatively little about what may regulate total bacterial carbon consumption in aquatic systems'. To date, direct measurements of DOC consumption are few because of the high precision needed to measure changes in DOC concentrations that are often as small as $1 \%$ and due to the extreme precautions necessary to ensure clean sampling techniques. Other recent studies by Zweifel (1999) and Moran et al. (1999) have focused on directly measuring DOC loss in estuarine waters. Moran et al. (1999) reported that $8 \%$ of the total pool was labile in 5 southeastern US estuaries on 1 to 2 mo timescales (calculated from DOC data reported in Table 1 of Moran et al. 1999), while Zweifel (1999) showed that 9\% was used during $7 \mathrm{~d}$ in the Gulf of Riga. These 2 studies, in conjunction with our data, suggest that only a small percentage of the total estuarine DOC pool is utilizable during bottle incubations on timescales relevant to estuarine residence times.

\section{Bacterial growth efficiencies}

Del Giorgio \& Cole (1998) reported that estimates of estuarine BGE are among the highest for aquatic and 
marine systems, and average $\sim 36 \%$. They attributed these high estuarine BGE values to high relative rates of primary production in estuaries. We made 18 estimates of BGE for the $5 \mathrm{~d}$ time points (Table 1), resulting in a grand average of $28 \pm 18 \%$. A similar average BGE of $29 \%$ (range 21 to $38 \%$ ) was also recently reported for the Laguna Madre estuary (Ziegler \& Benner 1999). While incubation times of $5 \mathrm{~d}$ may be considered long, del Giorgio \& Cole (1998) found that incubating samples for a number of days did not result in systematically lower BGE values. We observed no correlation between BGE and temperature, and a weak $\left(\mathrm{r}^{2}=0.17\right.$, $\mathrm{p}<0.1)$ relationship of decreasing BGE with increasing salinity (data not shown). We did observe a negative relationship between the concentration of labile DOC and BGE $\left(r^{2}=0.44, p<0.01\right)$. Another recent study used similar methods and incubation times in the Gulf of Riga (Zweifel 1999) to estimate BGE. Interestingly, Zweifel (1999) also reported the highest bacterial efficiencies during incubations that had relatively lower amounts of labile DOC.

\section{Internal source of labile DOC}

The York River estuary has a residence time of 1 to 2 mo (Sin et al. 1999). If there were no additional autochthonous inputs of labile DOC, the freshwater $\mathrm{G}_{1}$ and $\mathrm{G}_{2}$ pools would be removed during estuarine transport, causing the percent labile DOC to decrease with increasing salinity. For the $28 \mathrm{~d}$ incubation there was an initial decrease in the percent labile DOC from freshwater to salinity 5 (Fig. 4). This initial decrease is expected with the utilization of all of the freshwater $G_{1}$ pool in the first few days of transport, yet at salinities higher than 5, the percent labile DOC increases steadily. The increase in percent labile DOC with increasing salinity must have resulted from an input of labile DOC. Possible sources of this labile DOC in the York River estuary include: photo-oxidation of refractory DOC (Amon \& Benner 1996, Bano et al. 1998, Moran et al. 1999), efflux of DOC from sediment porewaters (Burdige \& Homestead 1994), phytoplankton exudation and zooplankton grazing (Cole et al. 1982, Baines \& Pace 1991), and marsh export (Peterson \& Howarth 1987, Dame 1994).

\section{Significance of DOC remineralization}

Previous work on the York River estuary has shown that it is net heterotrophic (Raymond et al. in press). That is, in the river, respiration exceeds gross primary production. One consequence of this net heterotrophy is the accumulation and subsequent evasion of $\mathrm{CO}_{2}$ from sur- face waters. Consequently, the net annual evasion of $\mathrm{CO}_{2}$ from the York River estuary must be balanced by the respiration of allochthonous organic matter. Benner et al. (1995) concluded that bacterial respiration accounted for 50 to $100 \%$ of community respiration in the Amazon. The DOC concentrations in river water entering the York River estuary are a factor of 6 greater than POC (data from the Chesapeake Bay Program: www.chesapeakebay.net), while bacterial production in the York River estuary is high relative to other systems (Schultz 1999). For these reasons, bacterial respiration of DOC is a likely mechanism supporting some percentage of net heterotrophy and $\mathrm{CO}_{2}$ super-saturation in this system. We used our monthly DOC consumption incubation results and an average bacterial growth efficiency of $28 \%$ to estimate the amount of $\mathrm{CO}_{2}$ produced by bacterial respiration of DOC in order to compare rates of bacterial $\mathrm{CO}_{2}$ production to $\mathrm{CO}_{2}$ evasion.

Fig. 6 compares the estimated bacterial $\mathrm{CO}_{2}$ production (i.e., respiration) with independent measurements

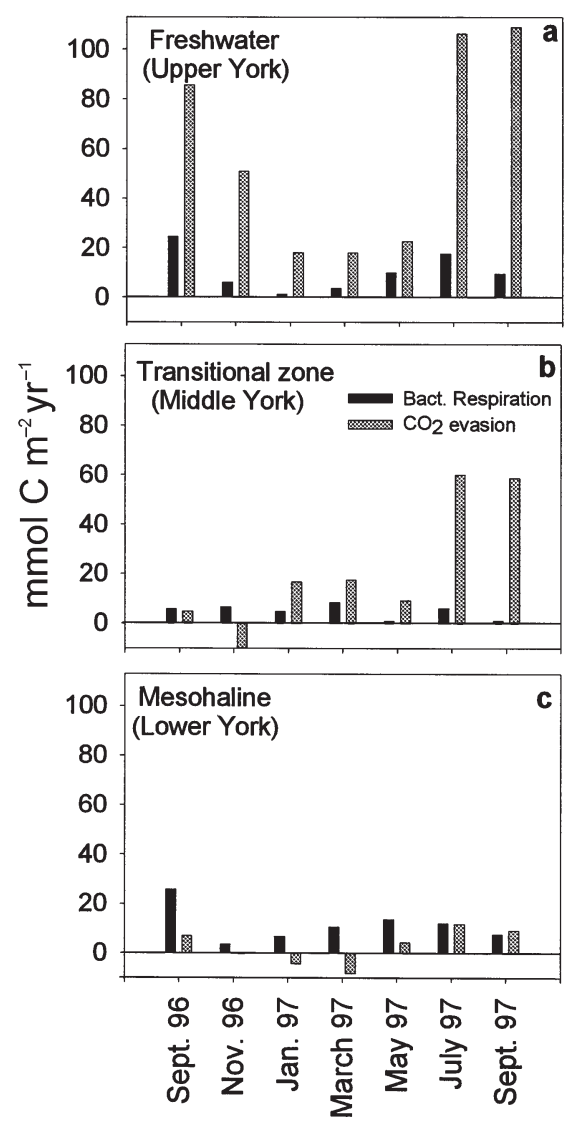

Fig. 6. Bacterial respiration and $\mathrm{CO}_{2}$ evasion for the (a) upper, (b) middle, and (c) lower York River estuary. $\mathrm{CO}_{2}$ evasion was determined by Raymond et al. (in press). Bacterial respiration was estimated by taking bacterial carbon utilization from transect incubations, assuming a bacterial growth efficiency of $28 \%$ (Table 1), and using average depths of 7.5, 3, and $6 \mathrm{~m}$ for the upper, middle, and lower York River estuary, respectively 
of $\mathrm{CO}_{2}$ evasion (from Raymond et al. in press) for the upper, middle, and lower York River estuary. On average, bacterial respiration of DOC within the water column can account for $20 \pm 12,43 \pm 39$, and $100 \pm 6 \%$ of $\mathrm{CO}_{2}$ evasion in the upper, middle, and lower York River estuary, respectively. As discussed previously, the lag in bacteria growth and respiration due to possible artifacts of filtration and confinement, and isolating bacteria from their sources of DOC, may cause an underestimate of bacterial respiration when expressed as a rate. For these reasons estimates of bacterial respiration in Fig. 6 are conservative. It is worth noting that even if these artifacts caused rates of bacterial respiration to be underestimated by a factor of 2 , bacterial respiration would still only account for $39 \%$ of $\mathrm{CO}_{2}$ evasion in the upper low salinity York River estuary (Fig. 6a).

The large discrepancy between bacterial respiration and $\mathrm{CO}_{2}$ evasion in the upper and middle York River estuary must therefore be balanced by another source of $\mathrm{CO}_{2}$. The remaining $\mathrm{CO}_{2}$ must arise from (1) watercolumn remineralization of organic carbon in the greater than $0.7 \mu \mathrm{m}$ size fraction (which includes riverine DOC that may flocculate and become POC), (2) sediment respiration, or (3) respiration in the expansive freshwater marshes associated with the upper York River estuary. In support of the latter, Cai et al. (1999) found that the marshes around the Satilla River, Georgia, USA, export $\mathrm{CO}_{2}$ to the mainstem.

A larger percentage of $\mathrm{CO}_{2}$ evasion in the middle and lower York River estuary can be balanced by bacterial respiration of DOC (Fig. 6b,c). This can be explained, in part, by changes in the ratio of net primary production (Pp) to bacterial respiration (BR) in the York River estuary. Due to light limitation and high flushing rates in the upper York River estuary, the middle and lower York River estuary have relatively higher rates of Pp for the majority of the year (Sin et al. 1999). This Pp consumes $\mathrm{CO}_{2}$ in surface waters. Because there is no subsequent significant increase in BR in the lower York River estuary (Fig. 6), there is a decrease in the net production of $\mathrm{CO}_{2}$ and therefore also in $\mathrm{CO}_{2}$ evasion. Therefore, higher rates of $\mathrm{CO}_{2}$ uptake (Pp) in the middle and lower York River estuary may explain why $\mathrm{CO}_{2}$ evasion and $\mathrm{CO}_{2}$ production from water column respiration are more closely balanced in these regions. This also provides an explanation for how bacterial $\mathrm{CO}_{2}$ production can actually exceed $\mathrm{CO}_{2}$ evasion for some months in the middle and lower York River estuary (Fig. 6b,c).

\section{Export of labile DOC from temperate estuaries}

The factorial experiments demonstrate that temperature, and not nutrient or DOC concentrations, is the major control on bacterial carbon consumption in the
York River estuary. Temperature control of bacterial production has also been observed in other temperate estuarine systems (Wright \& Coffin 1983, Hoch \& Kirchman 1993, Shiah \& Ducklow 1994, Findlay et al. 1996, Zweifel 1999). This suggests that there is a general relationship between temperature and bacterial carbon utilization across temperate estuaries. This is significant because DOC resides in rivers and estuaries for relatively short periods of time (days to months), and temperature constraints on bacterial carbon utilization will directly affect the amount of labile DOC that is exported. The relationship between temperature and bacterial carbon consumption was highly predictable in experiments in York River estuary waters (Fig. 5), and indicates that a larger percentage of the DOC pool can be used when temperature is elevated experimentally during winter and spring months.

Our results indicate that for every $1^{\circ} \mathrm{C}$ decrease below $25^{\circ} \mathrm{C}$, the percent of the DOC pool that is not consumed during a 1 mo incubation increases by $0.8 \pm$ $0.06 \%$. For example, $8 \%$ more DOC would be used by simply raising water temperatures from 15 to $25^{\circ} \mathrm{C}$. At typical York River riverine DOC concentrations $(\sim 400 \mu \mathrm{M})$, an increase of $8 \%$ with a $10^{\circ} \mathrm{C}$ temperature increase provides a $Q_{10}$ of 2.02 .

The DOC that is not used at lower temperatures is not inherently recalcitrant. It could be utilized if residence times were longer, or if temperatures were higher. Most estuaries discharging to the MAB have residence times that are similar to that of the York River estuary. We therefore deduce that a significant fraction of labile DOC passes through mid-Atlantic estuaries due to temperature constraints on mesophilic estuarine bacterial growth. This labile DOC ( $\mathrm{LDOC}_{\text {temp }}$ ) could be a significant percentage of the total amount of DOC exported, because flow rates and loading rates are high in the winter and spring when water temperatures are low.

The labile DOC that is not degraded as a result of temperature constraints, $\mathrm{LDOC}_{\text {temp, }}$ may be used in coastal waters due to 2 characteristics of the coastal ocean. First, temperatures in the MAB can reach as high as $28^{\circ} \mathrm{C}$, and a seasonal change in temperature could allow LDOC $_{\text {temp }}$ exported to the MAB in the winter to be oxidized during summer months. Furthermore, the highest temperatures are usually found in the southern reaches of the MAB. Sixty-five percent of the entire freshwater flow to the MAB is discharge directly into the southern $\mathrm{MAB}$, and freshwater flow entering the northern reaches of the MAB is transported south and close to the shore by prevailing currents (Wright \& Parker 1976). Second, the MAB has a much longer residence time than mid-Atlantic estuaries; estimates of mean residence times for water on the MAB range from $120 \mathrm{~d}$ (Mountain 1991) to $1.4 \mathrm{yr}$ (Fairbanks 1982). 
Table 3. Estimates of the annual export of labile DOC from the York River estuary due to temperature constraints on bacterial consumption of labile DOC ( $\left(\mathrm{LDCC}_{\text {temp }}\right.$ ). Factorial experiments indicate that for every $1^{\circ} \mathrm{C}$ decrease below $25^{\circ} \mathrm{C}, 0.8 \%$ of the total

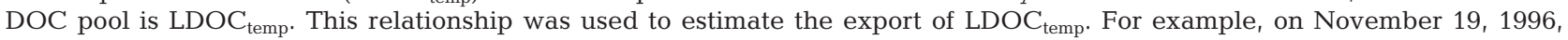
LDOC $_{\text {temp }}$ was estimated to be $53.3 \mu \mathrm{M}[(25-10) \times 0.008 \times 444.3]$. To obtain the export of total DOC and LDOC temp the respective concentrations were multiplied by flow rates and by the number of days separating sampling periods. In order to obtain an annual estimate (365 d) we began our year on July 1, 1996, and ended it on July 1, 1997

\begin{tabular}{|c|c|c|c|c|c|c|c|}
\hline $\begin{array}{l}\text { Date } \\
(\mathrm{mo} / \mathrm{d} / \mathrm{yr})\end{array}$ & $\begin{array}{l}\text { Temp. } \\
\left({ }^{\circ} \mathrm{C}\right)\end{array}$ & $\begin{array}{c}\text { Freshwater } \\
\text { DOC }(\mu M)\end{array}$ & $\begin{array}{l}\text { LDOC }_{\text {temp }} \\
(\mu \mathrm{M})\end{array}$ & $\begin{array}{l}\text { Flow } \\
\left(\mathrm{m}^{3} \mathrm{~s}^{-1}\right)\end{array}$ & $\begin{array}{l}\text { Days between } \\
\text { sampling }\end{array}$ & $\begin{array}{c}\text { TotalDOC } \\
\text { export } \\
\left(10^{10} \mathrm{mM}\right)\end{array}$ & $\begin{array}{c}\text { LDOC }_{\text {temp }} \\
\text { export } \\
\left(10^{10} \mathrm{mM}\right)\end{array}$ \\
\hline 07/10/96 & 27 & 458.0 & 0 & 19.4 & 10 & 0.8 & 0 \\
\hline 09/06/96 & 23 & 473.5 & 7.6 & 29.8 & 58 & 7.1 & 0.1 \\
\hline 11/19/96 & 10 & 444.3 & 53.3 & 53.2 & 74 & 15 & 1.8 \\
\hline 01/23/97 & 3 & 333.8 & 57.9 & 41.3 & 65 & 7.7 & 1.3 \\
\hline 03/24/97 & 10 & 390.1 & 45.2 & 64.4 & 60 & 13 & 1.5 \\
\hline 05/23/97 & 19 & 436.2 & 20.9 & 29.8 & 60 & 6.7 & 0.3 \\
\hline $07 / 18 / 97$ & 29 & 439.7 & 0 & 5.98 & 38 & 0.8 & 0 \\
\hline Annual export & & & & & & 51 & $\begin{array}{c}5.1 \\
(9.9 \%)\end{array}$ \\
\hline
\end{tabular}

As an estimate of the amounts of freshwater LDOC $_{\text {temp }}$ and total freshwater DOC exported from the York River estuary, riverine DOC measurements were combined with flow rates and the relationship between temperature and $\mathrm{LDOC}_{\text {temp }}\left(0.8 \%\right.$ per ${ }^{\circ} \mathrm{C}$ below $\left.25^{\circ} \mathrm{C}\right)$. The results are reported in Table 3. For the period of July 1,1996 , to July 1, 1997, an average of $9.9 \%$ of the total freshwater DOC pool was calculated to be

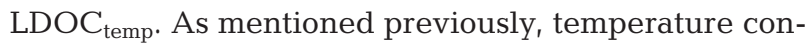
trols on bacterial production have been observed for many other temperate estuarine systems. We therefore assume to a first approximation that our estimate of $9.9 \%$ for the amount of freshwater labile DOC applies to all mid-Atlantic estuaries discharging to the MAB. This is a conservative estimate, because the Pamunkey River lies on the southern border of the MAB, and will therefore have higher winter/spring water temperatures than its northern counterparts.

The total annual freshwater flow to the MAB is $157 \mathrm{~km}^{3}$ (Wright \& Parker 1976), and average riverine DOC concentrations are $\sim 300 \mu \mathrm{M}$ (Table 4). Based on these values, approximately $47.1 \times 10^{9} \mathrm{~mol}$ of DOC are discharged from mid-Atlantic rivers annually. Of this DOC, $3.8 \times 10^{9} \mathrm{~mol}$ (or $8 \%$ based on York River incubations) are used by bacteria during transport through the estuary. Of the DOC remaining for export $(43.3 \times$ $\left.10^{9} \mathrm{~mol}\right), 4.3 \times 10^{9} \mathrm{~mol}(9.9 \%)$ are LDOC temp (Table 3$)$. The total surface area of the MAB shelf waters $(<200 \mathrm{~m}$ depth) is $120000 \mathrm{~km}^{2}$ (Wright \& Parker 1976). We therefore calculate that $4.3 \mathrm{~g}^{\mathrm{DOC} \mathrm{m}} \mathrm{m}^{-2} \mathrm{yr}^{-1}$ are transported through estuaries to the MAB and $0.5 \mathrm{~g} \mathrm{~m}^{-2} \mathrm{yr}^{-1}$

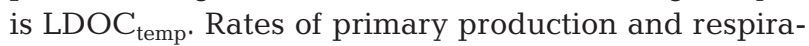
tion for the coastal ocean have been estimated at 160 and $158 \mathrm{~g} \mathrm{C} \mathrm{m}^{-2} \mathrm{yr}^{-1}$, respectively (Smith \& Hollibaugh 1993). This close balance makes it difficult to determine the metabolic state of coastal systems, and fluxes of 4.3 and $0.5 \mathrm{~g} \mathrm{C} \mathrm{m}^{-2} \mathrm{yr}^{-1}$ of DOC and LDOC respectively, may be important sources of allochthonous carbon supporting respiration in the MAB. Furthermore, we deem these conservative estimates because they do not account for DOC added within estuaries.

As indicated above, MAB waters have a residence time that is up to years longer than the residence times of mid-Atlantic estuaries. It is likely that water exported from mid-Atlantic rivers contains a third definable DOC fraction, or $\mathrm{G}_{3}$ fraction, that is less labile than the $G_{1}$ and $G_{2}$ fractions and is utilized on $1 \mathrm{yr}$ timescales (or timescales similar to residence times for the MAB). In our incubations, losses of DOC were still detectable after 28 d (Fig. 3). In addition, preliminary long-term incubations indicate that a large fraction of DOC was utilized during an incubation carried out for 1 yr (Raymond 1999). Fry et al. (1996) also observed significant DOC degradation in the latter stages of a $1 \mathrm{yr}$ incubation. The magnitude of the decay constant for the $\mathrm{G}_{2}$ fraction was approximately $50 \%$ of the $\mathrm{G}_{1}$ fraction. If we assume that the decay constant for the $\mathrm{G}_{3}$ fraction is $25 \%$ of the $\mathrm{G}_{2}$ decay constant, an addi-

Table 4. DOC concentrations for rivers discharging to the mid-Atlantic Bight (MAB). EPA data can be found at www.chesapeakebay.net

\begin{tabular}{|lcl|}
\hline River & DOC $(\mu \mathrm{M})$ & Source \\
\hline Susquehanna & 230 & Fisher et al. (1998) \\
Hudson & 330 & Findlay et al. (1996) \\
Delaware & 199 & Mannino \& Harvey (1999) \\
Potomac & 350 & (EPA data) \\
York & 430 & This study \\
Average & $307 \pm 83$ & \\
\hline
\end{tabular}


tional $20 \%$ (or $0.9 \mathrm{~g} \mathrm{C} \mathrm{m}^{-2} \mathrm{yr}^{-1}$ ) of the riverine DOC would be degraded in MAB waters. This would bring the total amount of riverine DOC used in MAB waters to $\sim 1.4 \mathrm{~g} \mathrm{DOC} \mathrm{m}^{-2} \mathrm{yr}^{-1}$ and raise the percentage total riverine DOC degraded to $40 \%$ (9\% consumed in the estuary, $9.9 \%$ LDOC $_{\text {temp, }}$ and $20 \% \mathrm{G}_{3}$ ). Moran et al. (1999) estimated bacterial consumption of freshwater riverine DOC within southeastern estuaries and adjacent shelf waters of the South Atlantic Bight to be $30 \%$, similar to our estimate for the MAB. If $40 \%$ of the riverine DOC pool is utilized in estuaries and on the MAB, $60 \%$ or $29 \times 10^{9} \mathrm{~mol}$ are available for export beyond the shelf-slope break annually.

\section{CONCLUSIONS}

The percentage of riverine DOC in the York River estuary removed by bacteria during estuarine transport is $\sim 10 \%$. The spatial dynamics of bacterial carbon consumption within the York River estuary indicate an internal source of labile DOC. Despite these inputs, bacterial DOC consumption cannot support $\mathrm{CO}_{2}$ evasion (i.e., net heterotrophy) in the upper York River estuary. For much of the year, the low percentage of DOC used by bacteria in the estuary is controlled by temperature constraints on bacterial carbon utilization. Low temperatures reduce utilization rates and, as a result of relatively short residence times $(\sim 1 \mathrm{mo})$, bacteria cannot consume all of labile DOC during its transport through the estuary.

Recently, other authors have also measured the loss of DOC during incubation of estuarine waters (Moran et al. 1999, Zwiefel 1999). These studies have also reported a labile pool that is generally smaller than in those studies reviewed by Søndergaard \& Middelboe (1995). Part of this discrepancy may be due to the reliance on indirect methods of DOC consumption (e.g., $\mathrm{O}_{2}$ consumption and thymidine incorporation) by previous authors. The ultimate fate of the majority of terrestrial/riverine DOC and its contribution to oceanic DOC pools is still unknown (Hedges et al. 1997). These new data on temperate estuaries indicate that a smaller percentage of the total terrestrial/riverine DOC pool may be removed by bacteria within the rivers and estuaries themselves than in adjacent coastal and continental shelf waters.

Acknowledgements. We thank M. Schrope for help with DOC analysis and H. Ducklow, J. Cole, I. Anderson, K. Moore, T. Hollibaugh, P. del Giorgio and an anonymous reviewer for comments on this manuscript. This work was supported by the Ocean Margins Program of the US Department of Energy (grant DE-FG05-94ER61833) and the Chemical Oceanography Program of the US National Science Foundation (grant OCE-9501531).

\section{LITERATURE CITED}

Amon RM, Benner R (1994) Rapid cycling of high-molecularweight dissolved organic matter in the ocean. Nature 369: 549-552

Amon RM, Benner R (1996) Photochemical and microbial consumption of dissolved organic carbon and dissolved oxygen in the Amazon River System. Geochim Cosmochim Acta 60:1783-1792

Baines SB, Pace ML (1991) The production of dissolved organic matter by phytoplankton and its importance to bacteria: patterns across marine and freshwater systems. Limnol Oceanogr 36:1078-1090

Bano N, Moran MA, Hodson RE (1998) Photochemical formation of labile organic matter from two components of dissolved organic carbon in a freshwater wetland. Aquat Microb Ecol 16:95-102

Basu BK, Pick FR (1997) Factors regulating heterotrophic bacterial and flagellate abundance in temperate rivers. Aquat Microb Ecol 12:123-129

Bauer JE, Williams PM, Druffel ER (1992) ${ }^{14} \mathrm{C}$ activity of dissolved organic carbon fractions in the North Central Pacific and Sargasso Sea. Nature 357:667-670

Bauer JE, Ruttenberg KC, Wolgast DM, Monoaghan E, Schrope MK (1996) Cross-flow filtration of dissolved and colloidal nitrogen and phosphorus in seawater: results from an intercomparison study. Mar Chem 55:33-52

Bender ME (1986) The York River: a brief review of its physical chemical and biological characteristics. Virginia Institute of Marine Science, Gloucester Point, VA

Benner R, Pakulski JD, McCarthy M, Hedges JI, Hatcher PG (1992) Bulk chemical characteristics of dissolved organic matter in the ocean. Science 255:1561-1564

Benner R, Opsahl S, Chin-Leo G, Richey JE, Forsberg BR (1995) Bacterial carbon metabolism in the Amazon River system. Limnol Oceanogr 40:1262-1270

Berner RA (1980) Early diagenesis. Princeton University Press, Princeton

Buesseler KB, Bauer JB, Chen RF, Eglinton TI, Gustafson O, Landing W, Mopper K, Moran SB, Santchi P, VernonClark R, Wells ML (1996) Sampling marine colloids using cross-flow filtration and results from an intercomparison study. Mar Chem 55:1-33

Burdige DJ, Homstead J (1994) Fluxes of dissolved organic carbon from Chesapeake Bay sediments. Geochim Cosmochim Acta 58:3407-3424

Cai WJ, Pomeroy LR, Moran MA, Wang Y (1999) Oxygen and carbon dioxide mass balance for the estuarine-intertidal marsh complexes of five rivers in the southeastern US. Limnol Oceanogr 44:639-649

Carlson CA, Bates NR, Ducklow HW, Hansell DA (1999) Estimation of bacterial respiration and growth efficiency in the Ross Sea Antarctica. Aquat Microb Ecol 19:229-244

Coffin RB, Fry B, Peterson BJ, Wright RT (1989) Carbon isotopic compositions of estuarine bacteria. Limnol Oceanogr 34:1305-1310

Coffin RB, Connolly JP, Harris PS (1993) Availability of dissolved organic carbon to bacterioplankton examined by oxygen utilization. Mar Ecol Prog Ser 101:9-22

Cole JJ, Likens GE, Strayer DL (1982) Photosynthetically produced dissolved organic carbon: an important carbon source for planktonic bacteria. Limnol Oceanogr 27: 1080-1090

Dame RF (1994) The net flux of materials between marshestuary systems and the sea: the Atlantic coast of the United States Global wetlands: old world and new. Elsevier, New York, p 295-302 
del Giorgio PA, Cole JJ (1998) Bacterial growth efficiency in natural aquatic systems. Annu Rev Ecol Syst 29:503-541

Ducklow HW (1982) Chesapeake Bay nutrient and plankton dynamics. 1. Bacterial biomass and production during spring tidal destratification in the York River estuary, Virginia. Limnol Oceanogr 27:651-659

Ducklow HW, Kirchman DL, Quinby HL (1989) Bacterioplankton cell growth and macromolecular synthesis in seawater cultures during the North Atlantic spring phytoplankton bloom. Microb Ecol 24:125-144

Fairbanks RG (1982) The origin of continental shelf and slope water in the New York Bight and Gulf of Maine: evidence from $\mathrm{H}_{2}{ }^{18} \mathrm{O} / \mathrm{H}_{2}{ }^{16} \mathrm{O}$ ratio measurements. J Phys Oceanogr 16:758-772

Ferguson RL, Buckley EN, Palumbo AV (1984) Response of marine bacterioplankton to differential filtration and confinement. Appl Environ Microbiol 47:49-55

Findlay S, Pace ML, Lints D, Howe K (1992) Bacterial metabolism of organic carbon in the tidal freshwater Hudson Estuary. Mar Ecol Prog Ser 89:147-153

Findlay SJ, Pace M, Fischer D (1996) Spatial and temporal variability in the lower food web of the tidal freshwater Hudson River. Estuaries 19:866-873

Fisher TR, Hagy JD, Rochell-Newall E (1998) Dissolved and particulate organic carbon in Chesapeake Bay. Estuaries 21:215-219

Fry B, Hopkinson CS, Nolin A (1996) Long-term decomposition of DOC from experimental diatom blooms. Limnol Oceanogr 41:1344-1347

Fuhrman JA (1990) Dissolved free amino acid cycling in an estuarine outflow plume. Mar Ecol Prog Ser 66:197-203

Gattuso JP, Frankignoulle M, Wollast R (1998) Carbon and carbonate metabolism in coastal aquatic ecosystems. Annu Rev Ecol Syst 29:405-434

Hedges JI, Keil RG, Benner R (1997) What happens to terrestrial organic matter in the ocean? Org Geochem 27: 195-212

Heip CH, Goosen NK, Herman PM, Kromkamp J, Middelburg JJ, Soetaert K (1995) Production and consumption of biological particles in temperate tidal estuaries. Oceanogr Mar Biol Annu Rev 33:1-149

Hobbie JE, Daley RJ, Jasper S (1977) Use of Nuclepore filters for counting bacteria by fluorescence microscopy. Appl Environ Microbiol 33:1225-1228

Hoch MP, Kirchman DL (1993) Seasonal and inter-annual variability in bacterial production and biomass in a temperate estuary. Mar Ecol Prog Ser 98:283-295

Hopkinson CS, Buffam I, Hobbie JE, Vallino J, Perdue M, Covert J, Hodson R, Moran MA, Smith E, Boross J, Findlay S, Forman K (1998) Terrestrial inputs of organic matter to coastal ecosystems: an intercomparison of chemical characteristics and bioavailability. Biogeochemistry 19:1-24

Howarth RW, Fruci JR, Sherman D (1991) Inputs of sediment and carbon to an estuarine ecosystem: influence of land use. Ecol Appl 1:27-39

Jahnke RA, Craven DB (1995) Quantifying the role of heterotrophic bacteria in the carbon cycle: a need for respiration measurements. Limnol Oceanogr 40:436-441

Kirchman DL, Suzuki Y, Garside C, Ducklow HW (1991) High turnover rates of dissolved organic carbon during a spring phytoplankton bloom. Nature 352:612-614

Koepfler ET (1989) Heterotrophic bacterial production in estuaries. PhD dissertation, Virginia Institute of Marine Science, Gloucester Point, VA

Mannino A, Harvey HR (1999) Lipid composition in particulate and dissolved organic matter in the Delaware Estuary: sources and diagenetic patterns. Geochim Cosmochim Acta 63:2219-2235

Editorial responsibility: James Hollibaugh,

Athens, Georgia, USA
Meybeck M (1982) Carbon, nitrogen, and phosphorus transport by world rivers. Am J Sci 282:401-450

Moran MA, Sheldon WM, Sheldon JE (1999) Biodegradation of riverine dissolved organic carbon in five estuaries of the southeastern United States. Estuaries 22:55-64

Mountain D (1991) The volume of shelf water in the middle Atlantic Bight: seasonal and interannual variability 1977-1987. Cont Shelf Res 11:251-259

Peterson BJ, Howarth RW (1987) Sulfur, carbon, and nitrogen isotopes used to trace organic matter flow in the saltmarsh estuary of Sapelo Island Georgia. Limnol Oceanogr 32:1195-1213

Peterson BJ, Fry B, Hullar M, Saupe S (1994) The distribution and stable carbon isotopic composition of dissolved organic carbon in estuaries. Estuaries 17:111-121

Raymond PA (1999) Carbon cyling in the York River estuary: an isotopic and mass balance approach using natural ${ }^{14} \mathrm{C}$ and ${ }^{13} \mathrm{C}$ isotopes. $\mathrm{PhD}$ dissertation, Virginia Institute of Marine Science, Gloucester Point, VA

Raymond PA, Bauer JE, Cole JJ (in press) Atmospheric $\mathrm{CO}_{2}$ evasion, $\mathrm{HCO}_{3}{ }^{-}$production, and net heterotrophy in the York River Estuary. Limnol Oceanogr

Roy S, Chanut JP, Gosselin M, Sime-Ngando T (1996) Characterization of phytoplankton communities in the lower $\mathrm{St}$ Lawrence Estuary using HPLC-detected pigments and cell microscopy. Mar Ecol Prog Ser 142:55-73

Schultz GE (1999) Bacterial dynamics and community structure in the York River estuary. PhD dissertation, Virginia Institute of Marine Science, Gloucester Point, VA

Shiah FK, Ducklow H (1994) Temperature regulation of heterotrophic bacterioplankton abundance production and specific growth rate in Chesapeake Bay. Limnol Oceanogr 39:1243-1258

Silberhorn GM, Zacherle AW (1987) King William County and town of West Point tidal marsh inventory \#289. Virginia Institute of Marine Science, Gloucester Point, VA

Sin Y, Wetzel RL, Anderson IC (1999) Spatial and temporal characteristics of nutrient and phytoplankton dynamics in the York River. Estuaries 22:260-265

Smith SV, Hollibaugh JT (1993) Coastal metabolism and the oceanic organic carbon balance Rev Geophys 31:75-89

Søndergaard M, Middelboe M (1995) A cross system analysis of labile dissolved organic carbon Mar Ecol Prog Ser 118: 283-294

Søndergaard M, Hansen B, Markager S (1995) Dynamics of dissolved organic carbon lability in a eutrophic lake. Limnol Oceanogr 46:46-54

Westrich JT, Berner RA (1984) The role of sedimentary organic matter in bacterial sulfate reduction: the $\mathrm{G}$ model tested. Limnol Oceanogr 29:236-249

Williams PM, Druffel ER (1987) Radiocarbon in dissolved organic carbon in the central north Pacific Ocean. Nature 330:246-248

Wright RT, Hobbie J (1965) The uptake of organic solutes in lake water. Limnol Oceanogr 10:22-28

Wright RT, Coffin RB (1983) Planktonic bacteria in estuaries and coastal waters of northern Massachusetts: spatial and temporal distribution. Mar Ecol Prog Ser 11:105-216

Wright WR, Parker CE (1976) A volumetric temperature and salinity census for the Mid-Atlantic Bight. Limnol Oceanogr 21:563-571

Ziegler S, Benner R (1999) Dissolved organic carbon cycling in a seagrass dominated lagoon. Mar Ecol Prog Ser 180: $149-160$

Zweifel UL (1999) Factors controlling accumulation of labile dissolved organic carbon in the Gulf of Riga. Estuar Coast Shelf Sci 48:357-370

Submitted: October 25, 1999; Accepted: April 24, 2000

Proofs received from author(s): July 13, 2000 